\title{
How Resources of Universities influence Industry Cooperation
}

\author{
Gyeong Min Nam ${ }^{1}$, Dae Geon $\mathrm{Kim}^{2}$ and Sang Ok Choi ${ }^{3, *}$ \\ 1 National Research Foundation of Korea, Daejeon 34113, Korea; lesoleil0913@gmail.com \\ 2 Department of Architectural \& Civil Engineering, Dong-seo University, Busan 47011, Korea; \\ gun43@hanmail.net \\ 3 Department of Public Administration, Korea University, Seoul 02841, Korea \\ * Correspondence: sangchoi@korea.ac.kr
}

Received: 19 June 2018; Accepted: 9 January 2019; Published: 15 February 2019

\begin{abstract}
In Korea, cooperation between university and company is mainly encouraged by government policy as the Triple Helix's statist model. Since 2003, the government started a variety of university financial support program, and in 2014, it reached to the point that 31 ministries conducted 408 programs in total. Most projects focused on training human resources and supporting Research and development, which is considered as the core function of universities, but some of the projects are designed to support the industry-academia cooperation. For instance, the Ministry of Education ran 'Leaders in University and Industry Cooperation (LINC)' program. LINC is a follow-up project of Human Resources Development for the Leading Industries, Industry-Academia Cooperation-oriented University, and Focal Point Research program. Accordingly, it aimed to create university-industry cooperative models, and nurture talents based on regional economy's demand. The program provided approximately $\$ 230 \mathrm{M}$ per year for over 50 universities across the country. It was one of the highly influential grant programs considering the fact that there are about 200 universities nationwide and an annual budget of university is $\$ 900$ billion on average. In this context, this study is to assess the influence of resources of universities capacity on the achievement of university-industry cooperation and explore whether a government-initiated policy has a significant effect using data from government information disclosure system on education.
\end{abstract}

Keywords: university-industry cooperation; triple helix; resource-dependent; open innovation; LINC

\section{Introduction}

Since the advent of the knowledge-based society in the 1980s, the world has started to change rapidly. Rapid globalization and informatization made the cycle of production, dissemination, and distribution of knowledge and technology shorter, which has led to the change of the paradigm of value creation. In the past, knowledge was discovered by a specific person or an institution, and the following added value could be created close to infinity once its value was recognized. Therefore, knowledge had was regarded as an object of protection. On the other hand, as knowledge and information are open to the public through the Internet and the global network is established, new ways of creating value by sharing knowledge and resources are attracting attention. As a result, companies have moved away from the closed innovation that was dependent on internal Research and development capability and pursue technological innovation through external exchange. Chesbrough (2006) defines this change as "open innovation" which means "the use of purposive inflows and outflows of knowledge to accelerate internal innovation, and expand the markets for external use of innovation, respectively". It assumes that firms can and should use external ideas as well as internal ideas, and internal and external paths to market, as they look to advance their technology. 
The role of the university has also changed with this trend. Since the 1980s, when the globalization began in earnest, developed countries such as the US and Europe have begun to pay attention to creating new growth engines based on science and technology in order to overcome the deterioration of national competitiveness in the world market. This turned out to be a change in the national policy. In order to enhance the national competitiveness by utilizing limited resources efficiently, they have promoted science and technology-oriented policy. Accordingly, investment of governments in liberal arts and fundamental sciences has been reduced and support for applied sciences has been increased with an expectation that those studies will enhance national competitive power in actual market. Since then, the concept of competition has been introduced into university support policies, and universities and professors have begun to work for external grants like the private sector. This has led to the paradigm shift to academic capitalism.

In Korea, cooperation between university and industry is mainly promoted by government. It can be interpreted by the Triple Helix's statist model [1-5]. Therfore, in this study, we assessed how universities capacity and government's policy affect on the achievement of university-industry cooperation. It aims to understand the organic relationship between industry, academia and government and to present policy implications.

\section{Key Literature Reviews}

\subsection{Resource-Dependence Theory}

The resource-dependence theory become one of the dominant theoretical rationales explaining how the external resources of organization have an impact on the organizational behavior. It is underpinned by the idea that resources are key factor for the operation and innovation. However, the theory assumes that resources inside the organization are basically insufficient in itself, and it choose to procure external resources to maintain the organization against constantly changing environment [6].

The following characteristics with respect to resource dependence: First, the more important resources are, the greater the dependency, which is based on the relative roof and criticality of the resource [6]. The criticality is the concept of the resilience of the organization to the resource. The lower the criticality, the higher the importance of the resource. Second, it is a relation between discretion and dependency over the resources' control. Direct control over resources can be achieved through the organization's access to resources or alliances with qualified institution. In other words, the higher the autonomy of the institution on resource utilization, the less reliance on the external environment. Third, there is a substitutionability of control. If the substitutionability of control over shared resources is low, then the sparseness of the resource is high Also the dependency is strengthened. Conversely, if an organization has control over the resources that are most likely to be replaced, then the dependence on those resources is also low. In other words, the dependency of the organization on the resource can be varied by the importance of the specific resource and the authority to control it. In addition, if the organization cannot secure the resources it considers important, it can acquire resources through cooperation with the organization having the resources.

This viewpoint provides the explanation on why organizations have only limited choices in the various issues they face. In the context of industry-academia cooperation, it means that industries lacking important resources such as $\mathrm{R}$ and D capability, financial support, professionals, and equipment would depend on universities that can supply the resources needed. Also universities and companies need to participate in industry-academia cooperation program to acquire financial resources.

\subsection{Triple Helix Model}

The Triple Helix model provides the idea that the hybridization of innovative elements from university, industry and government create innovation in production, transfer and application of knowledge [3]. It is defined by the system theory as a set of three elements: (i) components that the institutional spheres of university, industry, and government, with a wide array of actors; 
(ii) relationships between components (cooperation and conflict moderation, collaborative leadership, substitution and networking); and (iii) functions, described as processes taking place in what we label the 'Knowledge, Innovation and Consensus Spaces' [3,4]. This hybrid lead to an innovation of organization with a variety of systematic forms (Figure 1).

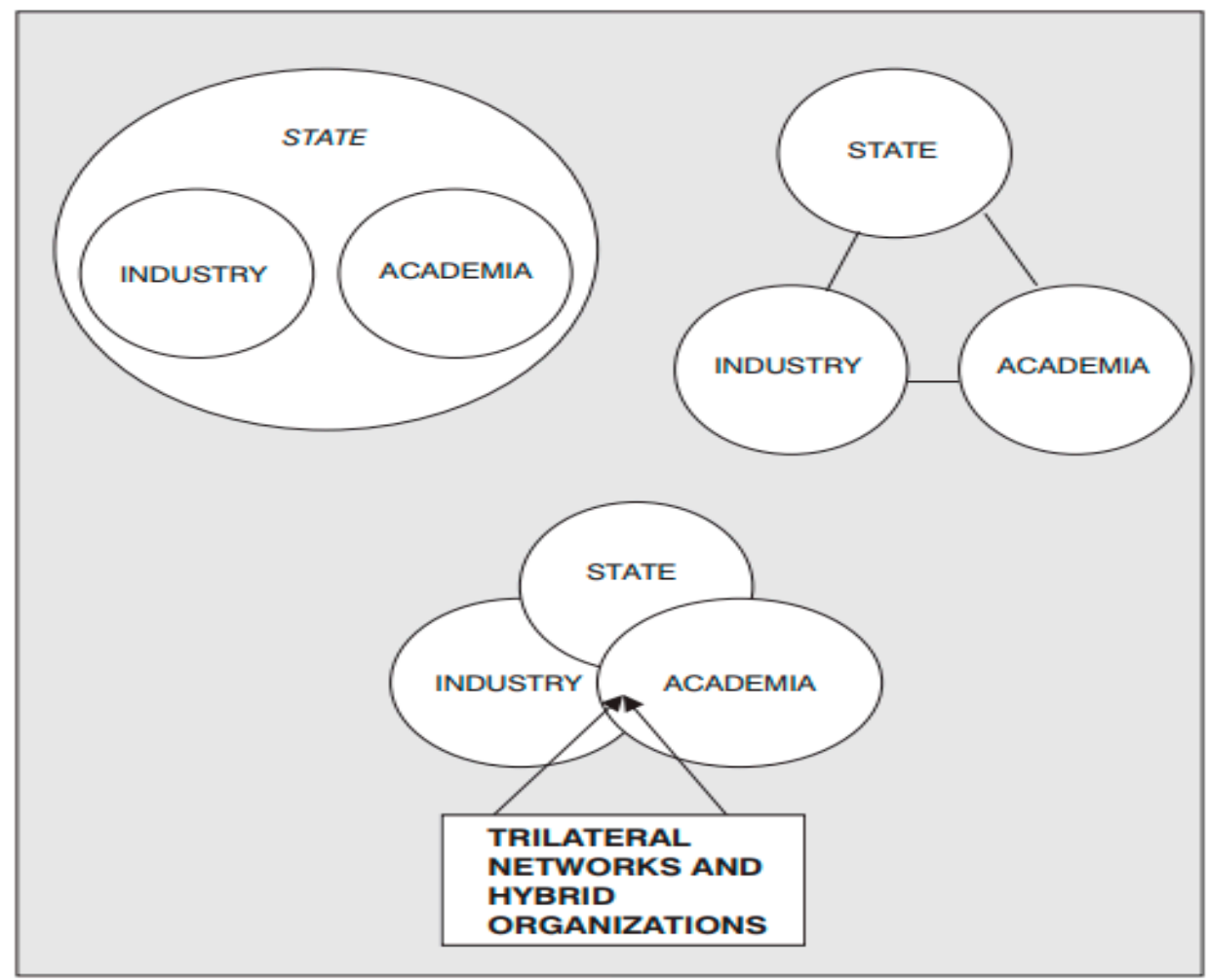

Figure 1. Triple Helix configurations.

The triple helix model can be divided into nationalism model, laissez-faire model, and interactive model. First, in the nationalism model, the state encompasses universities and industries, and forms direct relationships with them. At this time, the government acts as a coordinator to provide and coordinate resources for a new scheme. In general, however, government intervention is considered excessive, so this model is regarded as an unsuccessful model. Second, in the laissez-faire model, three pillars operate independently and the linkage among them is relatively loose. The university has a competence in basic research and training talent, and when it provides those to the private sector, the tacit knowledge is created through the enterprise. Even if there is no cooperation with corporates, universities may discover and create useful knowledge. Finally, in the interactive model, universities, governments, and firms share much of their role in the process. In the course of sharing, brand-new, innovative knowledge and breakthrough idea production take place, and each actor has a horizontal relationship. This is the core concept of the triple helix model, in which interaction and cooperation between universities, industries, and governments as relatively equal partners are increased, and the innovation and development derived from these increase social and economic development.

\subsection{Open Innovation}

$\mathrm{R}$ and $\mathrm{D}$ activities related to both products and processes are carried out only within the walls of the company, in a traditional point of view [7-10]. However, these are considered as barriers for new entrants that contribute to keep an advantage against competitors. A more open approach allows companies to get improved from ideas that would not be generated internally, but, fit perfectly the needs of the company. This model, whose term Open Innovation was coined by Chesbrough (2003), claims that "the company commercializes both its internal and external ideas from other companies, 
and search for ways to put their ideas on the market through the development of different routes that are not part of its usual business" [6].

\subsection{Factors Affecting University-Industry Cooperation (UIC)}

According to researchers, the performance of industry-university cooperation is measured by various indicators [11-14]. According to previous studies, university research capacity, resource capacity, and education capacity were used as factors influencing industry-university cooperation [15-17]. In detail, it was primarily measured by the number of patents, participants, and technology transfers and following revenue [18-20]. Also, the number of student start-ups, and university's educational support, such as capstone design programs, are considered as important factors (see Table 1) [11-22].

Table 1. Factors affecting university-industry cooperation (UIC).

\begin{tabular}{|c|c|c|}
\hline Researcher & Independent Variable & Dependent Variable \\
\hline $\begin{array}{c}\text { Byun Chang Ryul } \\
\text { (2004) }\end{array}$ & $\begin{array}{l}\text { Investment by government, private, and university } \\
\text { Management (inventor's share in royalties, size of } \\
\text { organization dedicated to technology transfer, } \\
\text { history of dedicated technology transfer } \\
\text { organization) } \\
\text { Technology infrastructure (university's science and } \\
\text { technology capacity, regional economy, size of } \\
\text { university) }\end{array}$ & $\begin{array}{l}\text { Academic achievements (SCI(E) * papers, } \\
\text { students' internship, number of graduate } \\
\text { students) } \\
\text { Technical achievements (technical guidance, } \\
\text { technology in possession) } \\
\text { Business performance (number of start-ups, } \\
\text { number of technology transfers and royalty } \\
\text { income) }\end{array}$ \\
\hline $\begin{array}{l}\text { Kim Cheol Hoe. } \\
\text { Lee Sang Don } \\
\quad(2007)\end{array}$ & $\begin{array}{l}\text { Research competency }(\mathrm{SCI}(\mathrm{E}) * \text { papers, } \\
\text { international and domestic patent registe) } \\
\text { Management competency (number of personnel } \\
\text { assigned to technology transfer, number of experts } \\
\text { in technology transfer organization) }\end{array}$ & $\begin{array}{l}\text { Technology transfer income } \\
\text { Number of technology transfer } \\
\text { Number of spin-off companies }\end{array}$ \\
\hline $\begin{array}{l}\text { Han Seung Hwan. } \\
\text { Kwon Ki Seok } \\
\text { (2009) }\end{array}$ & $\begin{array}{l}\text { Organizational characteristics (university } \\
\text { establishment, establishment type, size) } \\
\text { Research capacity (domestic and overseas papers } \\
\text { published) } \\
\text { R and D funding system (funding scale, funding } \\
\text { ratio) } \\
\text { Research environment (location) }\end{array}$ & $\begin{array}{l}\text { Achievement of cooperation between } \\
\text { industry and academia (number of patent } \\
\text { applications in domestic and foreign } \\
\text { countries, number of technology transfer } \\
\text { and profit) }\end{array}$ \\
\hline $\begin{array}{l}\text { Kim Gyeong Jin } \\
\text { (2010) }\end{array}$ & $\begin{array}{l}\text { Internal competence (the size of the organization } \\
\text { dedicated to technology transfer, the number of } \\
\text { patent applications, funding) } \\
\text { External environment (location, Connect Korea } \\
\text { participation, ndustry recognition) }\end{array}$ & Technology transfer income \\
\hline $\begin{array}{l}\text { Joh Hyun Jeong } \\
\qquad(2012)\end{array}$ & $\begin{array}{l}\text { Resource capacity (the number of graduate school } \\
\text { students, the total amount of research expenses) } \\
\text { Organizational competence (number of personnel } \\
\text { assigned to technical transfer, number of } \\
\text { professionals) }\end{array}$ & $\begin{array}{l}\text { Patent performance (domestic and foreign } \\
\text { patent applications for } 3 \text { years) } \\
\text { Technology transfer performance (number } \\
\text { of technology transfer, revenue) } \\
\text { Entrepreneurial achievements (number of } \\
\text { professor founding a company, sales of } \\
\text { professor start-ups) }\end{array}$ \\
\hline $\begin{array}{l}\text { Lim Eui Ju. } \\
\text { Kim Chang Wan. } \\
\text { Jo Geun Tae } \\
\text { (2013) }\end{array}$ & $\begin{array}{l}\text { Number of personnel ssigned to technical transfer } \\
\text { Number of personnel dedicated to incubation }\end{array}$ & $\begin{array}{l}\text { Achievement of industry-university } \\
\text { cooperation (number of technology transfer, } \\
\text { income, number of start-up and its revenue) }\end{array}$ \\
\hline $\begin{array}{c}\text { Nah Sang Min. } \\
\text { Kim Chang Wan·Lee Hee sang } \\
\text { (2014) }\end{array}$ & $\begin{array}{l}\text { Tenured professor's experience in private sector } \\
\text { The number of professionals } \\
\text { Number of faculty support students start-up } \\
\text { Number of universities with technology holding } \\
\text { companies } \\
\text { Number of courses for founding }\end{array}$ & $\begin{array}{l}\text { Technology transfer and commercialization } \\
\text { achievement (technology transfer fee per } \\
\text { tenured faculty, number of student } \\
\text { founders of students' start-ups) }\end{array}$ \\
\hline
\end{tabular}

* Science Citation Index Expanded.

\section{Data Collection and Research Methods}

\subsection{Research Model}

The purpose of this study is to figure out how the university's capability affects actual performance by using government statistics. In accordance with the literature review, we divided independent variables into following three groups; (1) University faculty's capability, (2) Government policy, 
(3) Student support programs. The index that we set to assess the effectiveness is technology transfer output and students' employment including start-ups (Figure 2).

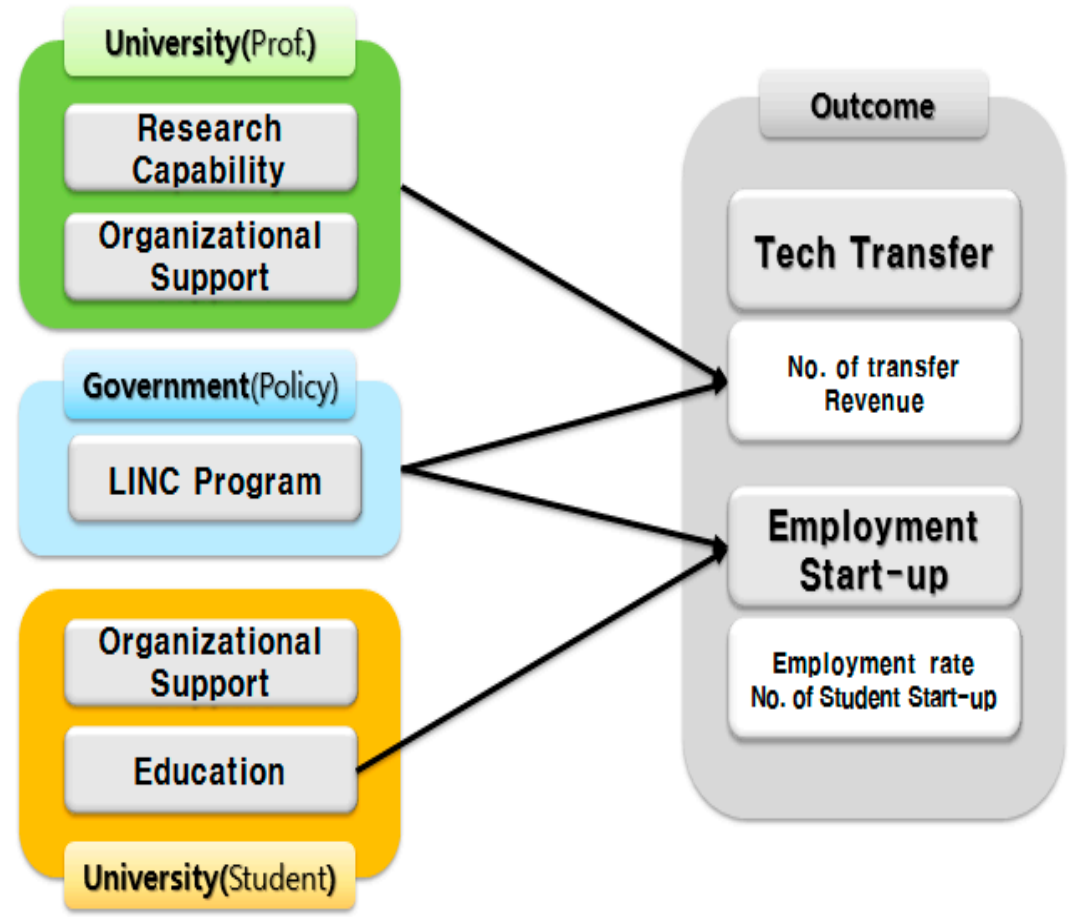

Figure 2. Research Model.

The hypothesis based upon the research model is as follows:

Research capability of university teachers (number of SCI (E) or SCOPUS theses per tenured faculties, number of domestic and foreign patent registrations, average number of $R$ and $D$ projects and funding), universities' organizational competence (number of employees, professionals, and UIC professors) and LINC project has a positive impact on enhancing the technology commercialization performance.

Universities' educational support (number of students on field training, percentage of students who completed capstone design, number of start-up class), universities' organizational competence (number of employees, professionals, and UIC professors), and LINC project has a positive impact on student start-up and employment.

\subsection{Approach and Method}

The analysis was conducted in the following way, taking into account the characteristics of individual variables and the purpose of the study. First, we test the independence and normality of variables to determine whether basic assumptions are satisfied before regression analysis. In order to check whether the variables are regularly distributed, each of the skewness and kurtosis are observed. When the regularity is not satisfied, the variables are converted according to the preceding research. In addition, we used a correlation analysis to pre-verify the existence of multiple collinearity between independent variables. Also, the independence between variables was confirmed by using the variance inflation factor (VIF) in regression analysis. The independence between the error terms was tested using the Durbin-Watson statistic.

After confirming the basic assumption, we conducted multiple regression analysis to observe the relations between independent variables and dependent variables. Since the variables were converted after the normality test, multiple regression analysis was performed according to OLS (ordinary least squares). Windows SPSS 22.0 program was used for analysis. 


\section{Research Results}

In order to identify how university capacity of university-industry cooperation affects its performance, we conducted multiple regression analysis. Dependent and independent variables were determined through literature review. The former is university faculty's capability, government-initiated policy, student support programs. The latter are identified as achievement in technology transfer, and student employment. The results of analyzing the data shown in Table 2.

Table 2. Analysis result.

\begin{tabular}{|c|c|c|c|c|c|}
\hline \multirow{2}{*}{\multicolumn{2}{|c|}{ Dependent variable }} & \multicolumn{2}{|c|}{ Technology Transfer } & \multicolumn{2}{|c|}{ Employment } \\
\hline & & $\begin{array}{c}\text { No. of } \\
\text { Contract }\end{array}$ & Revenue & $\begin{array}{l}\text { Employment } \\
\text { Rate }\end{array}$ & $\begin{array}{l}\text { No. of Student } \\
\text { Start-up }\end{array}$ \\
\hline \multirow{2}{*}{$\begin{array}{l}\text { Research } \\
\text { Capability }\end{array}$} & $\begin{array}{c}\text { Tenured Prof's } \\
\text { SCI(E)/SCOPUS article }\end{array}$ & & $(+)$ & & \\
\hline & $\begin{array}{c}\text { No. of } \\
\text { Tenured Prof's }\end{array}$ & $(+)$ & & & \\
\hline \multirow{3}{*}{$\begin{array}{l}\text { Educational } \\
\text { Capability }\end{array}$} & $\begin{array}{l}\text { No. of Student Who Competed } \\
\text { Placement }\end{array}$ & & & & \\
\hline & $\begin{array}{l}\text { No. of Student Completed } \\
\text { Capstone Design }\end{array}$ & & & & \\
\hline & No. of Start-up Lectures & & & & $(+)$ \\
\hline \multirow{3}{*}{$\begin{array}{l}\text { Organizational } \\
\text { Capability }\end{array}$} & $\begin{array}{c}\text { No. of employee of UIC } \\
\text { department }\end{array}$ & & & & \\
\hline & $\begin{array}{c}\text { Percentage of regular employree } \\
\text { of UIC department }\end{array}$ & $(+)$ & & $(+)$ & \\
\hline & No. of UIC Professor & & & $(-)$ & \\
\hline $\begin{array}{c}\text { Government's } \\
\text { Financial } \\
\text { Support }\end{array}$ & LINC Grant & $(+)$ & & $(+)$ & \\
\hline
\end{tabular}

In this study, multiple regression analysis was conducted using university information disclosure data for the last three years in order to verify the effect of university competence on university-industry cooperation performance, and the effectiveness of government policy. Through the review of the previous research and theoretical review, the performance of the industry-university cooperation was measured by the technology commercialization, and student start-up and employment outcome. it was assumed that the research capacity, education capacity and organizational capacity of the university had a positive effect on UIC performance. Furthermore, the government's financial support for universities is expected to show a positive relationship with it. The results of the research model are as follows:

First, it is found that the number of patents registered by full-time faculty members, the percentage of regular employee of UIC group, and the financial support from the government via LINC contributes to the increase of technology transfer. Also, the higher the number of SCI(E) and SCOPUS articles published by participating professors, the higher revenue from technology transfer.

Second, the educational capacity and organizational capacity of the university and the government funding have a significant effect on the employment rate. The employment rate of students was influenced by, the percentage of regular employee of UIC group, the number of UIC professor, and government financial support. The ratio of the total workforce of the UIC department and the government funding have a positive effect on improving the employment rate of graduates, while the number of UIC professors was negative. 


\section{Discussion}

\subsection{Summary}

The results of the hypothesis tests on the factors influencing the technical commercialization performance of the above universities are summarized in Table 2. First, research capacity of the university has a significant effect on the technical commercialization performance. Specifically, the average number of patents of full-time faculty is higher than that of technology transfer, and the average number of papers of full time faculty members has a positive effect on technology transfer. The organizational capacity was analyzed to have an influence only on the number of technology transfers. In addition, the LINC project has a significant effect on the increase of the number of technology transfers. In conclusion, it can be interpreted that a high level of research and policy enhancement is necessary to improve technology transfer performance.

\subsection{Limits and Further Improvement}

The implications of this study are as follows.

This study has a signification for verifying the factors influencing industry-university cooperation performance by activities of industry, academia and government based on triple spiral model and resource dependency theory. In the previous research, they only focused the relationship between government and university or university and industry segmentally. In this study, we considered the linkage among all the actors when establishing the research model, and analyzed the factors affecting the university-industry cooperation.

In terms of the policy, some improvements are needed. First, it is necessary to improve the patent support system of universities. Following the result of the study, the patent registration of faculty contributed to the quantitative expansion of technology commercialization, but, did not have a significant effect on creating the profits in practice. Therefore, it needs to be improved in terms of quality via improving the technology valuation system based on market trend analysis. Second, it is necessary to improve a curriculum of placement and capstone design so that companies can participate in the process and reflect actual demand in the field. Analysis shows that the effectiveness of the two curricula is extremely low. To solve this problem, universities need to strengthen networks with local communities and companies and urge them to participate in curriculum design. Finally, the UIC professor system is also considered to be ineffective, it is necessary to draw up the reform plan through follow-up study on the recognition of the UIC professor, environment and obstacles. In addition, from the viewpoint of resource dependency, it seems possible to establish policies to promote bilateral cooperation by grasping the demand of industry, and university.

Nevertheless, this study has the following limitations. Despite the existence of time series data on the same group, there was a lack of correlation test between them. Also, there was a lack of consideration for the corporate-driven activities due to the low accessibility and a lack of data. In the following research, the research model should focus on the industry-academia cooperation conducted by the company as a primary actor.

Author Contributions: G.M.N. did conceptualization, Data Curation, Formal analysis and Writing-Original draft preparation; D.G.K. did concepts on the modeling, and writing of the manuscript; S.O.C. did Validation, riting-Review\& Editing, Supervision and Project Administration.

Funding: The publishing fee of this paper was supported by the DGIST R\&D Program of the Ministry of Science, Technology and ICT (DGIST-IT-18-01).

Conflicts of Interest: The authors declare no conflict of interest.

\section{References}

1. Etzkowitz, H. Entrepreneurial Scientists and Entrepreneurial Universities in American Academic Science. Minerva 1983, 21, 198-233. [CrossRef] [PubMed] 
2. Etzkowitz, H.; Leydesdorff, L. The Triple Helix-University-industry-government relations: A laboratory for knowledge based economic development. EASST Rev. 1995, 14, 14-19.

3. Etzkowitz, H.; Leydesdorff, L. The dynamics of innovation: From National Systems and "Mode 2" to a Triple Helix of university-industry-government relations. Res. Policy 2000, 29, 109-123. [CrossRef]

4. Etzkowitz, H. Triple Helix: A Manifesto for Innovation, Incubation and Growth; SNS Press: Stockholm, Sweden, 2003.

5. Leydesdorff, L. The mutual information of university- industry-government relations: An indicator of the Triple Helix dynamics. Scientometrics 2003, 58, 445-467. [CrossRef]

6. Pfeffer, J.; Salancik, G.R. The External Control of Organizations: A Resource Dependence Perspective; Stanford University Press: Palo Alto, CA, USA, 2003.

7. Yun, J.J.; Won, D.; Park, K. Dynamics from open innovation to evolutionary change. J. Open Innov. Technol. Mark. Complex. 2016, 2, 7. [CrossRef]

8. Yun, J.J.; Jeong, E.; Yang, J. Open innovation of knowledge cities. J. Open Innov. Technol. Mark. Complex. 2015, 1, 16. [CrossRef]

9. Leydesdorff, L. Synergy in Knowledge-Based Innovation Systems at National and Regional Levels: The Triple-Helix Model and the Fourth Industrial Revolution. J. Open Innov. Technol. Mark. Complex. 2018, 4, 16. [CrossRef]

10. Park, H.S. Technology convergence, open innovation, and dynamic economy. J. Open Innov. Technol. Mark. Complex. 2017, 3, 24. [CrossRef]

11. Siegel, D.S.; Waldman, D.; Link, A. Assessing the impact of organizational practices on the relative productivity of university technology transfer offices: An exploratory study. Res. Policy 2003, 32, 27-48. [CrossRef]

12. Wei, J. The University Library's Recommending System with the Personalized Recommending Functions. Int. J. u-e-Serv. Sci. Technol. 2015, 8, 203-210. [CrossRef]

13. Lee, H.S.; Yoel, L.S. Analysis of Various Influences and Factors on Academic Persistence of Cyber University Students. Int. J. u- e-Serv. Sci. Technol. 2015, 8, 211-222. [CrossRef]

14. Lee, S.Y.; Ju, H.Y. Effects of Participating in Mentoring Activities for Self Leadership and Super Leadership Development in University Students. Int. J. u-e-Serv. Sci. Technol. 2015, 8, 151-160. [CrossRef]

15. Park, M.S.; Han, S.H. Structural Analysis on University Students Who Participated in the Courses of the Lifelong Educator in Consciousness of Lifelong Education, Everyday Creativity, Leadership, Cognitive Learning Competency and Life Core Competencies. Int. J. u- e-Serv. Sci. Technol. 2015, 8, 11-22. [CrossRef]

16. Lu, R. University Teaching and Research and Scientific Research Performance Quantitative Statistics System Based on Web. Int. J. u- e-Serv. Sci. Technol. 2016, 9, 185-194. [CrossRef]

17. Shao, Y. Influence of Study Abroad on University Knowledge Innovation. Int. J. u- e-Serv. Sci. Technol. 2016, 9,99-106.

18. Lee, S.Y.; Lee, H.S. Analysis of the Effect of University Specialization of Academic Fields on University Education Outcomes. Int. J. u-e-Serv. Sci. Technol. 2016, 9, 365-376. [CrossRef]

19. Yu, L.; Liu, Z. Performance Prediction Model of University Students Based on the Grey BP Neural Network. Int. J. u-e-Serv. Sci. Technol. 2016, 9, 265-272. [CrossRef]

20. Mahmood, N.; Cai, J.; Hina, M.; Farhan, J.; Anum, N. The Role of University-Based Incubators in Developing Economies: Empirical Evidence from Pakistan. Int. J. u-e-Serv. Sci. Technol. 2016, 9, 143-152. [CrossRef]

21. Sreedhar, G. Analyzing Download Time Performance of University Websites in India. Int. J. u- e-Serv. Sci. Technol. 2014, 1, 1-6. [CrossRef]

22. Kim, S.-K. Analysis on the Effect of University Restructuring on University Finance Changes in Korean. Asia-Pac. J. Educ. Manag. Res. (AJEMR) 2016, 1, 7-14. [CrossRef]

(C) 2019 by the authors. Licensee MDPI, Basel, Switzerland. This article is an open access article distributed under the terms and conditions of the Creative Commons Attribution (CC BY) license (http:/ / creativecommons.org/licenses/by/4.0/). 